\title{
Allelopathic potential of Medicago arborea, a Mediterranean invasive shrub
}

\author{
Anne Bousquet-Mélou, Sophie Louis, Christine Robles, Stéphane Greff, Sylvie Dupouyet and \\ Catherine Fernandez
}

Institut Méditerranéen d'Ecologie et Paléoécologie (IMEP) - UMR CNRS 6116, Laboratoire de Biosystématique et d'Ecologie Méditerranéenne (LBEM), Université de Provence, Centre de St. Jérôme, Case 421 bis, 13397 Marseille, Cedex 20, France.

\begin{abstract}
Summary. Biological invasions are nowadays a major problem in ecology. Allelopathy has been shown to be involved in such invasions, but this mechanism has been little studied in France. The objectives of this study were to evaluate the allelopathic potential of Medicago arborea, an invasive species in the French Mediterranean region. Foliar extracts were tested on three target species (Lactuca sativa, Lepidium sativum and Linum strictum). We showed that Medicago arborea has high allelopathic potential to affect the growth and germination of other species. Yellow flax (Linum strictum), native to the invaded area, was the most sensitive of the tested plant species to foliar extracts of Medicago arborea. Our study pointed out the role of allelopathy in processes leading to biological invasion, and more generally in population dynamics.
\end{abstract}

Key words: allelopathy - biological invasion - population dynamics - biodiversity - phenolic compounds - Medicago arborea (Fabaceae, Fabales, Rosidae).

\section{Introduction}

Globalisation of the world trade market has caused widespread introduction of exotic species at a worldwide scale. Introduced species make up a large part of the flora and fauna in most regions of the world (Mack and D'Antonio, 1998), and introduction of non-native species can either be rewarding or a plague to the society (Lambinon, 1997; Ewel et al., 1999, Vivanco et al., 2004). Numerous introduced species play fundamental roles in the economy and culture of many countries (e.g. food, medical industry and horticulture). However, some of these species are spreading into the wild where they become invasive and have profound negative impacts on native ecosystems (Williamson, 1996). Successful invasions often results in irreversible homogenisation of plant communities (Wiser et al., 1998). Biological invasions are thought to be the second largest threat, after the destruction or fragmentation of habitats, to sustaining

Correspondence to: Anne Bousquet-Mélou, e-mail: anne.bousquetmelou@univ.u-3mrs.fr biodiversity at a global scale (D'Antonio and Vitousek, 1992; Williamson, 1996, 1999).

The circum-Mediterranean region is an important pool of global biodiversity (Myers in Médail and Quézel, 1997), apparently due to specific climatic conditions, the diverse origin of the flora, habitat heterogeneity, and geological, paleogeographical and historical factors. For example, in south of France, there are 215 endemic taxa, which represent $7.2 \%$ of the regional flora (Médail and Verlaque, 1997). Preservation of this biological heritage is important.

Current research on biological invasion has focused on (i) characteristics of habitats most likely to be invaded (Orions, 1986; Crawley, 1987; Huenneke et al., 1990; Harrington, 1991; Bruke and Grime, 1996; Wiser et al., 1998), including the role of perturbation for facilitating invasions (Hobbs and Huenneke, 1992; D’Antonio et al., 1999), (ii) processes of invasion (Vivrette and Muller, 1977; Zedler and Scheid, 1998; D’Antonio, 1993; Vila and D'Antonio, 1998), including characteristics (ecological, physiological and biological attributes) of species most likely to be invasive (Hulst et al., 1987; Noble, 1989; Albert, 1995; Binggeli, 1996; Rejmanek, 1996; Reichard, 1997), and to a lesser extent (Alvarez, 1999) (iii) impacts of invasive species on ecosystems. Many studies have been carried out on competition, while few studies have looked at allelopathic potential among invasive species and its role in the invasion process (Bais et al., 2003; Hierro and Callaway, 2003).

Among vascular plants, almost all allelochemicals are secondary metabolites, and their impacts on ecosystems have been studied for several years (Rice, 1984). These studies have permitted to anticipate variations in their toxicity with regard to their ecological and seasonal context. It has been shown that allelopathic component play an important role in the regulation of plant diversity (Chou, 1999).

We chose to study Medicago arborea L. (Fabaceae, Fabales). Its widespread distribution is a result of human cultivation and use as ornamental plant or to prevent soil erosion (Andreu et al., 1998). This African species has spread mainly along the coast in the vicinity of houses in residential areas where it used to be planted, but it has also been recorded as invasive in the Mediterranean region. The aim of this study is to analyse allelopathic potential of this introduced plant species, in order to understand the role of 
this phenomenon in the processes of succession and on the regulation of biodiversity of plant communities.

\section{Material and methods}

Plant Material. M. arborea, tree medic, originating from Africa, is a woody perennial plant species that can reach $2 \mathrm{~m}$ in height. Sampling of plant material was made along the coast in the municipality of Martigues (Bouches-du-Rhône, south-eastern France). Leaves from five individuals of similar age were sampled at all heights in dense, almost mono-specific, stands. Sampling was carried out in October before leaf fall. Leaves were frozen and then oven-dried at $30^{\circ} \mathrm{C}$ until constant weight.

Chemical Analyses. Aqueous extracts of compounds were prepared by soaking $249.4 \mathrm{~g}$ fresh leaves in $1,150 \mathrm{~g}$ distilled water for 48 hours in darkness at $4{ }^{\circ} \mathrm{C}$. The obtained solution was filtered and freeze-dried to give $11.35 \mathrm{~g}$ of yellow powder. A mass of $200 \mathrm{mg}$ of the powder was dissolved in $25 \mathrm{ml}$ water (HPLC quality Millipore-St-Quentin, France) and the solution was extracted three times with $25 \mathrm{ml}$ ethyl acetate (SDS-Peypin, France). The three organic fractions were gathered and concentrated to dryness with rotary evaporator. The resulting residue was suspended in $1 \mathrm{ml}$ of methylene chloride (SDS-Peypin, France) and transferred to a $5 \mathrm{ml}$ vial. The procedure was repeated three times. The collected solution was evaporated to dryness under a stream of helium, and $500 \mu \mathrm{l}$ of methylene chloride was then once again added, then evaporated, to remove residual water.

For GC-MS analysis, $200 \mu \mathrm{l}$ of Derivative reagent, N,Obis(trimethylsilyl)trifluoroacetamide (BSTFA) containing $1 \%$ trimethylchlorosilane (TMCS) (purchased by Fluka-Sigma Aldrich), was used and an equal volume of acetonitrile (SDSPeypin, France) was added to produce trimethylsilyl derivatives. The solution was incubated at $70{ }^{\circ} \mathrm{C}$ for 1 hour.

Analyses were performed using a Hewlett-Packard GC6890 coupled to a HP 5973N Mass Detector. Separation of the analytes was achieved by using a HP5 MS capillary column of $30 \mathrm{~m}$ length $\times$ $0.25 \mathrm{~mm}$ I.D. $\times 0.25 \mu \mathrm{m}$ film thickness (J\&W Scientific). Sample volumes of $2 \mu \mathrm{l}$ were injected in a splitless mode for $1 \mathrm{~min}$ with an ALS 7683 Automatic Injector. Purge flow was set to $30 \mathrm{ml} / \mathrm{min}$. Helium $(99.995 \%)$ was used as carrier gas. Initial head pressure was kept at $8.22 \mathrm{psi}$ and a constant flow of $1 \mathrm{ml} / \mathrm{min}$ was set throughout the run. Initial oven temperature was programmed at $70{ }^{\circ} \mathrm{C}$, and was gradually increased to $220^{\circ} \mathrm{C}$ at a rate of $3{ }^{\circ} \mathrm{C} / \mathrm{min}$, where it remained constant for $10 \mathrm{~min}$. Injector temperature and MSD transfer line heater were kept constant at 250 and $280^{\circ} \mathrm{C}$, respectively. Mass spectrometer parameters for EI mode were: ion source, $230{ }^{\circ} \mathrm{C}$; MS quadrupole, $150{ }^{\circ} \mathrm{C}$; electron energy, $70 \mathrm{eV}$; electron multiplier energy, $1150 \mathrm{~V}$; acquisition in scan mode from 40 to 500 amu.

Bioassays. Allelochemicals are released into the environment through 4 principal pathways: decomposition of litter, root exudates in the soil, vaporisation into the air, and rain and dew transfering leaf compounds to the soil (Rice, 1984). Some authors have shown that water-soluble compounds are, probably, those compounds most likely to be involved in allelophathy (Vyvyan, 2002). We have chosen to approach natural leachates in this study by testing foliar aqueous extracts.

A base solution of $20 \mathrm{~g} \mathrm{l}^{-1}$ was prepared from $4 \mathrm{~g}$ of foliar tissue and $200 \mathrm{ml}$ of deionised water (Molina et al., 1991; BongSeop, 1992; Vyvyan, 2002). The extract was left for 27 hours in a refrigerator $\left(4{ }^{\circ} \mathrm{C} \pm 2{ }^{\circ} \mathrm{C}\right)$, shaken occasionally, and was then filtered through Whatman No. 4 paper. This base solution was then used for preparing dilutions of $5 \mathrm{~g} \mathrm{l}^{-1}, 10 \mathrm{~g} \mathrm{l}^{-1}$, and $20 \mathrm{~g} \mathrm{l}^{-1}$.

The allelopathic potential of leaves of Medicago arborea was tested on seeds from three species: garden cress (Lepidium sativum L., Brassicaceae, Brassicales), lettuce (Lactuca sativa L. c.v. battavia, Asteraceae, Asterales), and yellow flax (Linum strictum L., Linaceae, Linales). These species are known for their sensitivity to allelopathic substances. Lettuce and garden cress are frequently used for bioassays (Heisey, 1990; Lawrence et al., 1991). Yellow flax was chosen because it naturally grows in Mediterranean ecosystems, S France, and because it is sensitive to allelochemicals
(Deleuil, 1950). Seeds of the first two species were bought in local commerce while seeds of the latter species were obtained through the botanical garden of Marseille.

Trials were carried out using glass Petri dishes $(9 \mathrm{~cm}$ diameter) and Whatman paper No. 4. Twenty seeds were placed in each Petri dish, to which $2 \mathrm{ml}$ of foliar extract was added, except for controls that received $2 \mathrm{ml}$ deionised water. Seeds were sprayed every 24 hours with the original test extract to avoid dessication and to reflect natural conditions during rain: target plants are assumed to be in contact with allelochemicals, or with deionised water in the case of controls. For each dose, five replicates were used.

Trials were carried out at room temperature (approximately $20{ }^{\circ} \mathrm{C}$ and natural photoperiod). Germination rate and response curve, as well as the growth of seedlings (length of the radicle and hypocotyl, and total length) were measured.

Statistical Analyses. Comparison of germination rate between treatments was tested using a Chi-square test (Scherrer, 1984). Differences in mean length (radicle, hypocotyl and total length) were tested using analyses of variance (one-way ANOVA). Prior to analyses, data was tested for normality and homogeneity of variance by Shapiro-Wilks' and Bartlett's tests, respectively. Statistical analyses were carried out using Statgraphics ${ }^{\circledR}$ (version 2.1).

\section{Results}

Chemical Analyses. Analyses of M. arborea leaves demonstrated the presence of 4-hydroxybenzoic, vanillic and p-coumaric acids. Salicylic acids was also identified. Other, non-phenolic, acids such as succinic, palmitic, azelaic, lactic, dehydroabietic acids were as well identified (Table 1).

Effects on Germination. Germination rate varied between 48 and 99\%, depending on species and dose (Fig. 1). Yellow flax was the only target species that had lower germination rate in the presence of foliar extracts of $M$. arborea, and this was significant only at highest dose $\left(20 \mathrm{~g} \mathrm{l}^{-1}\right.$; Khi 2 test, $\mathrm{p}<0.05$ ). Additionally, the germination rate of yellow flax seeds was lower at the highest dose (complete germination was not reached until 12 days after initiation of the experiment, Fig. 2).

Effects on Growth. Foliar extracts of M. arborea strongly reduced growth of seedlings for all three target species (One-way Anova, p < 0.05; Fig. 3). The inhibition of growth was particularly pronounced for extracts at doses 10 and $20 \mathrm{~g} \mathrm{l}^{-1}$. It must further be emphasised that the reduction in growth was simultaneously observed on hypocotyl and radicle only at the highest dose, and this was consistent for all three target species (One-way Anova, $\mathrm{p}<0.05$; Fig. 3). At lower doses, inhibition of growth mainly affected the radicle. The effect of extract solutions on the radicle was particularly important for $L$. strictum and L. sativa. Indeed, necrosis was observed for the entire radicle at high doses (Fig. 3). It must also be underlined that a stimultating effect on the growth of hypocotyl of L. sativum was observed at low doses $\left(5 \mathrm{~g} \mathrm{l}^{-1}\right)$ (One-way Anova, $\mathrm{p}<0.05$; Fig. 3).

\section{Discussion}

Several authors have shown that invasive plants often form dense, mono-specific stands in their new habitats (Bais et al., 2003) though it this density is quite rare in the natural environments of these same species. Such monocultures 
Table 1 Chemical compounds extracted from Medicago arborea leaves. RT: retention time (minutes) of compounds in the column. Surface of the peaks in the chromatogram is expressed as a percentage

\begin{tabular}{|c|c|c|c|c|}
\hline RT & COMMON NAME & SCIENTIFIC NAME & Surf $(\%)$ & CAS \\
\hline & Aliphatic acids & & & \\
\hline $\begin{array}{r}7.47 \\
9.18 \\
13.92 \\
16.74 \\
22.16 \\
27.29 \\
29.55 \\
34.91 \\
36.39 \\
42.70 \\
48.47\end{array}$ & $\begin{array}{l}\text { Lactic acid } \\
\text { 2-Hexenoic acid } \\
\text { Succinic acid, ethyl ester } \\
\text { Succinic acid } \\
\text { Capric acid } \\
\beta \text {-Phenyllactic acid } \\
\text { Lauric acid } \\
\text { Azelaic acid } \\
\text { Myristic acid } \\
\text { Palmitic acid } \\
\text { Stearic acid }\end{array}$ & $\begin{array}{l}\text { Propanoic acid, 2-hydroxy- } \\
\text { 2-Hexenoic acid } \\
\text { Butanedioic acid, monoethyl ester } \\
\text { Butanedioic acid } \\
\text { Decanoic acid } \\
\text { Benzenepropanoic acid, } \alpha \text {-hydroxy- } \\
\text { Dodecanoic acid } \\
\text { Nonanedioic acid } \\
\text { Tetradecanoic acid } \\
\text { Hexadecanoic acid } \\
\text { Octadecanoic acid }\end{array}$ & $\begin{aligned} & 2.0 \\
& 0.5 \\
< & 0.5 \\
& 12.1 \\
< & 0.5 \\
< & 0.5 \\
< & 0.5 \\
& 2.9 \\
& 1.4 \\
& 3.2 \\
& 1.3\end{aligned}$ & $\begin{array}{l}50-21-5 \\
1191-04-4 \\
1070-34-4 \\
110-15-6 \\
334-48-5 \\
828-01-3 \\
143-07-7 \\
123-99-9 \\
544-63-8 \\
57-10-3 \\
57-11-4\end{array}$ \\
\hline 48.47 & Aliphatic alcohols & & & \\
\hline \multirow[t]{2}{*}{15.43} & Glycerol & 1,2,3-Propanetriol & 2.2 & $56-81-5$ \\
\hline & Bases & & & \\
\hline \multirow[t]{2}{*}{$\begin{array}{l}17.73 \\
20.28\end{array}$} & $\begin{array}{l}\text { 2,4-Pyrimidinediol } \\
\text { 2,4-Pyrimidinediol, 5-methyl- }\end{array}$ & $\begin{array}{l}\text { 2,4-Pyrimidinediol } \\
\text { 2,4-Pyrimidinediol, 5-methyl- }\end{array}$ & $\begin{array}{l}4.0 \\
2.5\end{array}$ & $\begin{array}{l}51953-14-1 \\
80289-22-1\end{array}$ \\
\hline & Phenolic alcohols & & & \\
\hline $\begin{array}{l}12.93 \\
21.44 \\
26.65 \\
29.32\end{array}$ & $\begin{array}{l}\text { Phenylethyl alcohol } \\
\alpha \text {-hydroxy-o-cresol } \\
\alpha \text {-hydroxy-p-cresol } \\
\text { Vanillic alcohol }\end{array}$ & $\begin{array}{l}\text { Benzeneethanol } \\
\text { Benzenemethanol, 2-hydroxy- } \\
\text { Benzenemethanol, 4-hydroxy- } \\
\text { Benzenemethanol, 4-hydroxy-3-methoxy- }\end{array}$ & $\begin{array}{r}0.7 \\
<0.5 \\
2.5 \\
<0.5\end{array}$ & $\begin{array}{l}60-12-8 \\
90-01-7 \\
623-05-2 \\
498-00-0\end{array}$ \\
\hline 29.32 & Phenolic aldehydes & & & \\
\hline 23.10 & $\begin{array}{l}\text { 3-Resorcylic aldehyde } \\
\text { (or Gentisaldehyde) } \\
\text { Vanillin }\end{array}$ & $\begin{array}{l}\text { Benzaldehyde, 2,4-dihydroxy- } \\
\quad \text { (or Benzaldehyde, 2,5-dihydroxy-) } \\
\text { Benzaldehyde, 4-hydroxy-3-methoxy- }\end{array}$ & $\begin{array}{r}3.9 \\
< \\
<0.5\end{array}$ & $\begin{array}{l}95-01-2 \\
1194-98-5 \\
121-33-5\end{array}$ \\
\hline 25.05 & Phenolic acids and esters & & & \\
\hline $\begin{array}{l}24.40 \\
13.69 \\
27.91\end{array}$ & $\begin{array}{l}\text { Salicylic acid } \\
\text { Benzoic acid } \\
\beta \text {-Resorcylic acid, methyl ester } \\
\text { (or Gentisic acid, methyl ester) }\end{array}$ & $\begin{array}{l}\text { Benzoic acid, 2-hydroxy- } \\
\text { Benzoic acid } \\
\text { Benzoic acid, 2,4-dihydroxy-, } \\
\text { methyl ester (or Benzoic acid, } \\
\text { 2,5-dihydroxy-, methyl ester) }\end{array}$ & $\begin{array}{l}5.3 \\
2.8 \\
2.5\end{array}$ & $\begin{array}{l}69-72-7 \\
65-85-0 \\
2150-47-2 \\
2150-46-1\end{array}$ \\
\hline $\begin{array}{l}28.71 \\
29.20 \\
33.76 \\
34.42\end{array}$ & $\begin{array}{l}\text { 4-Hydroxybenzoic acid } \\
\text { 4-Hydroxybenzeneacetic acid } \\
\text { Vanillic acid } \\
\beta \text {-Resorcylic acid } \\
\text { (or Gentisic acid) }\end{array}$ & $\begin{array}{l}\text { Benzoic acid, 4-hydroxy- } \\
\text { Benzeneacetic acid, 4-hydroxy- } \\
\text { Benzoic acid, 4-hydroxy-3-methoxy- } \\
\text { Benzoic acid, 2,5-dihydroxy- } \\
\quad \text { (or Benzoic, 2,4-dihydroxy-) }\end{array}$ & $\begin{array}{r}1.4 \\
<0.5 \\
2.0 \\
<0.5\end{array}$ & $\begin{array}{l}99-96-7 \\
156-38-7 \\
121-34-6 \\
89-86-1 \\
490-79-9\end{array}$ \\
\hline 38.39 & $\begin{array}{l}\text { Syringic acid } \\
\text { Cinnamic acids }\end{array}$ & Benzoic acid, 3,5-dimethoxy-4-hydroxy- & $<0.5$ & $530-57-4$ \\
\hline 34.52 & $\begin{array}{l}\text { p-Coumaric acid } \\
\text { Others }\end{array}$ & 2-Propenoic acid, 3-(4-hydroxyphenyl)- & 2.4 & $7400-08-0$ \\
\hline 52.49 & Dehydroabietic acid & $\begin{array}{l}\text { 1-Phenanthrenecarboxylic acid, } \\
\text { 1,2,3,4,4a,9,10,10a-octahydro-1,4a-dimethyl- } \\
\text { 7-(1-methylethyl)-(1R,4aS,10aR)- }\end{array}$ & 3.3 & $1740-19-8$ \\
\hline $\begin{array}{l}21.36 \\
32.09\end{array}$ & $\begin{array}{l}\text { 2,3-Dihydroxybutyrolactone } \\
\text { Non identified }\end{array}$ & $\begin{array}{l}\text { 2(3H)-furanone, dihydro-3,4-dihydroxy } \\
\mathrm{m} / \mathrm{z}=303\end{array}$ & $\begin{array}{r}<0.5 \\
7.2\end{array}$ & $13092-55-2$ \\
\hline
\end{tabular}

suggest that unusually strong interactions may be occurring, such as allelopathy, during the establishment of invasive plant species, in addition to competition for environmental resources (Abdul-Wahab and Rice, 1967; Vaughn and Berhow, 1999; Callaway and Aschehoug, 2000, Ridenour and Callaway, 2001).
Medicago species are known to contain water soluble compounds such as phenolic acids and derivatives (Xuan et al., 2005), and terpenoids (Miller, 1996) that are allelopathic to other species (Oleszek et al., 1999, Chon et al., 2002). In this study, we chose to focus our analysis on low molecular weight compounds. 


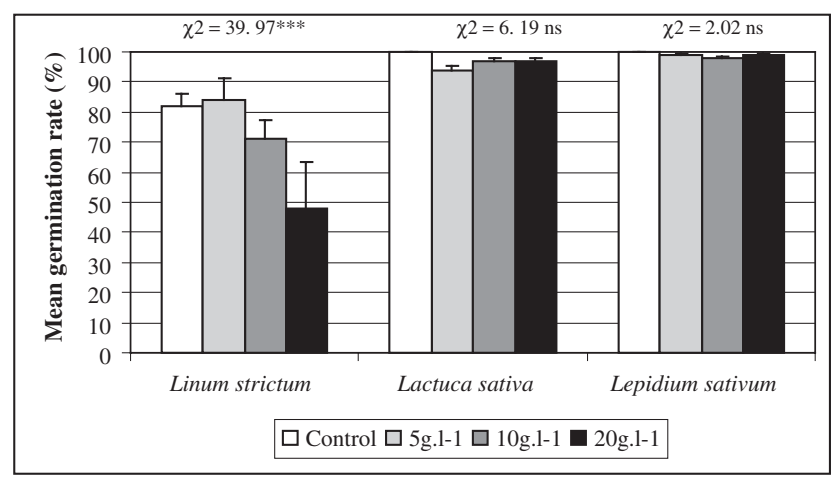

Fig. 1 Mean germination rate of the tree target species (confidence interval at $95 \%$ ) according to the dose of the extract of Medicago arborea. Results of Chi-Square test are also presented ( $\chi^{2}$ value and $\mathrm{p}: * * * \mathrm{p}<0.001 ;$ ns: non-significant)

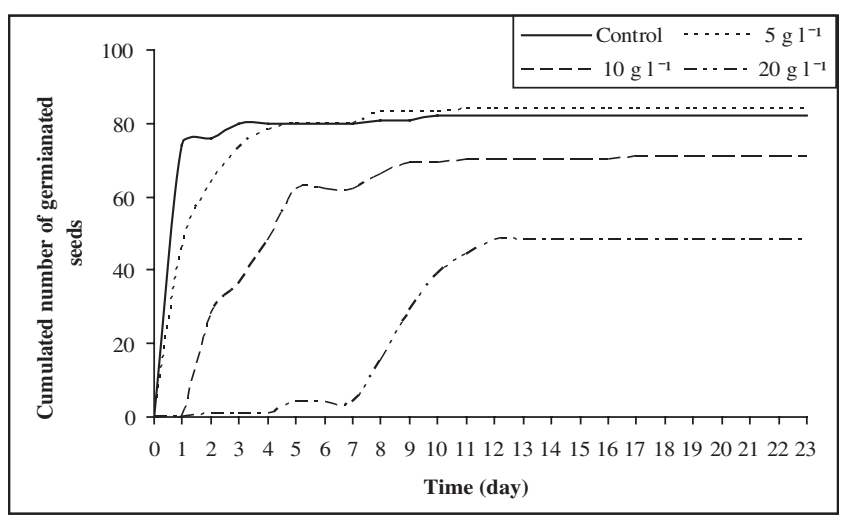

Fig. 2 Germination curve of Linum strictum seeds according to the dose of the extracts of Medicago arborea.
Phenolic compounds, found in this study, such as p-coumaric, 4-hydroxybenzoic and, vanillic acid, had already been detected in leaves of $M$. arborea (Torck and Pinkas, 1980). All these compounds may be involved in potential allelopathic effects of this species. Many phenolic compounds appear to have allelochemical effects (Rice, 1984; Bong-Seop, 1992). Furthermore, compounds such as dihydroabietic or salicylic acid have been described as allelochemicals (Quayyum et al., 1999; Chung et al., 2000). Leaves of $M$. arborea contain thus compounds that could have, after being released in the environment as leachates or litter exudates, allelopathic effects on other plants.

Our results show that leaf extracts of $M$. arborea have a noticeable allelopathic effect on the different tested species. Even if bioessay on cress and lettuce do not demonstrate the importance of allelopathy in invasions, the use of these species shows the possible mechanism by which Medicago competes with natives. Moreover, the results concerning yellow flax, which grows in the study area, have more ecological significance.

In allelopathy studies, $10 \%$ extracts are commonly used (Rutherford et Powrie, 1993; Laterra et Bazzalo, 1999). This concentration of allelochemicals is probably higher than those found in fields, but it reveals an allelopathic potential from the donor plant (Bong-Seop, 1992). Different stages of the target species' life cycle were affected: germination (rate and response curve) as well as growth, particularly for yellow flax (species growing naturally in the environment). In this way, $M$. arborea could, through compounds present in their leaves, limit the establishment of other species by reducing interspecific competition (Reigosa et al., 2000), or by affecting the growth of species already present in the environment. In particular, phytotoxic compounds released by $M$. arborea gave raise to, at high concentrations, a total necrosis in the radicle of the three target species. This

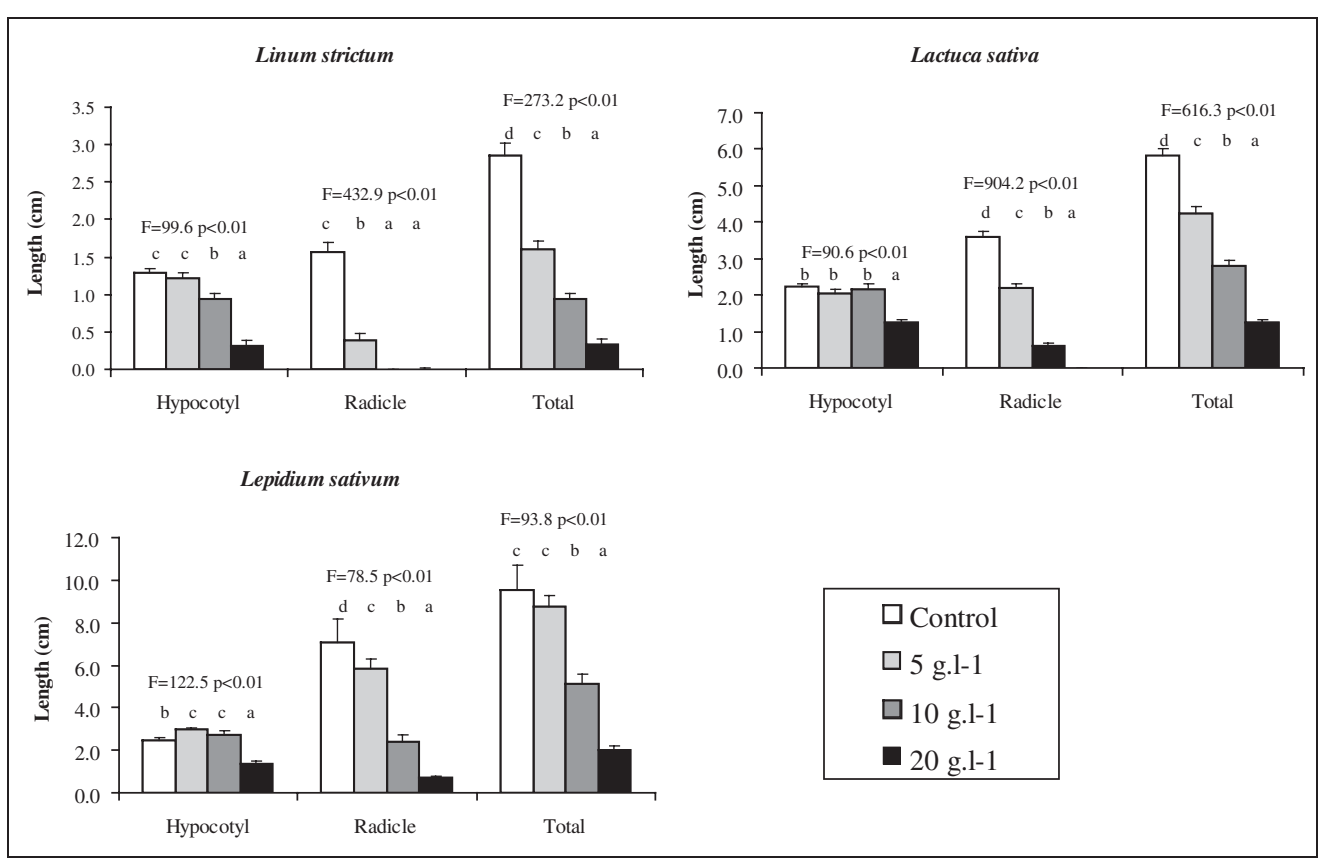

Fig. 3 Mean of radicle, hypocotyl and total length (confidence interval at $95 \%$ ) of Linum strictum, Lactuca sativa, Lepidimum sativum as a function of tested dose. Results of Anova tests (F- and p-value) and posthoc tests on length are also presented. Values not differing at $5 \%$ are denoted with the same letter 
allelopathic damage could affect the competitiveness of plants. Resource competition and allelopathy should be considered together as processes that simultaneously affect the growth and population dynamics of other species (Nilsson 1996, Ridenour and Callaway, 2001). Their relative importance can vary depending on species and ecological context (Callaway and Aschehoug, 2000; Hierro and Callaway, 2003) such as the invasion by exotic species. Callaway and Aschehoug (2000) have by the way shown that the advantage of an invasive species over a native species appears to be due to root exudates and their effects on competition for resources. Such competitive mechanisms, that are not naturally present in the habitats invaded by exotic species, could interact with inherently coevolved interactions among longassociated native species (Callaway and Aschehoug, 2000). Allelopathy could thus play a more important role in the invasion process when the plants present in the colonised environment appear to be more sensitive to allelochemicals than the invasive species (Williamson, 1990). It has been shown that not only plants but also soil micro-organisms could possess an inherent resistance against allelochemicals in their natural environment while this resistance is not effective against invading exotic species (Vivanco et al., 2004). In the same way, our results showing a high sensitivity of the species naturally present in the environment (Linum structum) towards the allelochemicals of $M$. arborea, compared to the commercialised species, could be due to lacking resistance against aggressive mechanisms involved in the invasion of this exotic species.

Our study shows that $M$. arborea possesses allelopathic potential. Allelopathic potential of $M$. arborea could favour its establishment in the environment that it colonises, whether it is limiting interspecific competition or access to resources, which could result in profound modifications of the colonised environments' biodiversity.

\section{Acknowledgments}

We would like to thank Dr Régine Verlaque for her help in this study and to Anders Mårell for correcting the English. We also like to thank Dr Virginie Baldy, Dr Nathalie Korboulewsky and the two anonymous referees for their comment and valuable criticism.

\section{References}

Abdul-Wahab AS, Rice EL (1967) Plant inhibition by Johnson grass and its possible significance in old-field succession Bull Torrey Bot Club 94: 486-497

Albert ME (1995) Portrait of an Invader II: The Ecology and Management of Carpobrotus edulis CalEPPC News Spring 1995

Alvarez ME (1999) Community level consequences of a biological invasion: Effects of a non-native vine on three plant communities MS Sonoma State University.

Andreu V, Rubio JL, Gimeno-Garcia, E, Llinares JV (1998) Testing three Mediterranean scrub species in runoff reduction and sediment transport Soil and Tillage Research 45: 441-454

Bais HP, Vepachedu R, Gilroy S, Callaway RM, Vivanco JM (2003) Allelopathy and exotic plants: from genes to invasion Science 301: 1377-1380

Binggeli P (1996) A taxonomic, biogeographical and ecological overview of invasive woody plants J Veg Sci 7: 121-124
Bong-Seop K (1992) Effect of pine allelochemicals on selected species in Korea. Pp. 204-241 in Rizvi SJH, Rizvi V (eds) Allelopathy: Basic and applied aspects. GB-London: Chapman \& Hall publ

Burke MJW, Grime JP (1996) An experimental study of plant community invisibility Ecology 77: 776-790.

Callaway RM, Aschehoug, ET (2000) Invasive plants versus their new and old neighbors: a mechanism for exotic invasion Science 290: 521-523

Chon SU, Choi SK, Jung S, Jang HG, Pyo BS, Kim SM (2002) Effect of alfalfa leaf extracts and phenolic allelochemicals on early seedling growth and root morphology of alfalfa and barnyard grass Crop protection 21: 1077-1082

Chou CH (1999) Roles of Allelopathy in Plant Biodiversity and Sustainable Agriculture Plant Sci 18(5): 609-636

Crawley MJ (1987) What makes a community invasible? Pp 429-453 Gray AJ, Crawley MJ, Edwards PJ (eds) Colonizers, succession and stability. GB-Oxford: Blackwell Scientific Publications

Chung IM, Seigler D, Miller DA, Kyung SH (2000) Autotoxic coumpound from fresh Alfalfa leaf extracts: identification and biological activity J Chem Ecol 26(1): 315-326

D'Antonio CM, Dudley TL, Mack M (1999) Disturbance and biological invasions: Direct effects and feedbacks in Walker L (ed) Ecosystems of Disturbed Ground Amsterdam: Elsevier Press.

D'Antonio CM (1993) Mechanisms controlling invasion of coastal plant communities by the alien succulent Carpobrotus edulis Ecology 74: 83-95

D'Antonio CM, Vitousek PM (1992) Biological invasions by nonindigenous grasses, the grass/fire cycle, and global change Ann Rev Ecol Syst 23: 63-87

Deleuil G, transmise par Emberger L (1950) Explication de la présence de certains thérophytes rencontrés parfois dans les associations du Rosmarino-Ericion. Académie des sciences séance du 25 juin 1951. 2477.

Ewel JJ, O'Dowd DJ, Bergelson J, Daehler CC, D'Antonio CM, Gomez D, Gordon DR, Hobbs RJ, Holt A, Hopper KR, Hughes CE, Lahart M, Leakey RRB, Lee WG, Loope LL, Lorence DH, Louda SM, Lugo AE, Mcevoy PB, Richardson DM, Vitousek PM (1999) Deliberate introductions of species: research needs? Benefits can be reaped, but risks are high. BioScience 49: 619-630

Harrington GN (1991) Effect of soil moisture on shrub seedling establishment and survival in a semi-arid grassland. Ecology 72: $1138-1149$

Heisey RM (1990) Allelopathic and herbicidal effects of extracts from tree of heaven (Ailanthus altissima). Am J Bot 77(5): $662-670$

Hierro JL, Callaway RM (2003) Allelopathy and exotic plant invasion. Plant Soil 256: 29-39

Hobbs RJ, Huenneke LF (1992) Disturbance, Diversity, and Invasion: Implications for Conservation. Conserv Biol 6: 324-337

Huenneke LF, Hamburg SP, Koide R, Mooney HA, Vitousek PM (1990) Effects of soil resources on plant invasion and community structure in California serpentine grassland. Ecology 71: 478-491

Hulst RB, Shiply B, Theriault A (1987) Why is Rhinanthus minor (Scrophulariaceae) such a good invader? Can. J Bot 65: 2373-2379

Lambinon J (1997) Introduction of non-native plants into the natural environment. Nature and environment [Council of Europe]. 87: 29p

Laterra P, Bazzalo ME (1999) Seed-to-seed allelopathic effects between two invaders of burned Pampa grasslands. Weed Research 39: 297-308

Lawrence JG, Colwell A, Sexton OJ (1991) The ecological impact of allelopathy in Ailanthus altissima (simaroubaceae). Am J Bot 78(7): 948-958

Mack MC, D'Antonio CM (1998) Impacts of biological invasions on disturbance regimes. Trends Ecol Evol 13: 195-198

Médail F, Quézel P (1997) Hot-spots analysis for conservation of plant biodiversity in the Mediterranean Basin. Mediterranean Plant Biodiversity 84(1): 112-127 
Médail F, Verlaque R (1997) Ecological characteristics and rarity of endemic plants from S-E. France and Corsica. Implications for biodiversity conservation. Biol Conserv 80: 269-281

Miller DA (1996) Allelopathy in forage crop systems Agronomy Journal 88: 854-859

Molina A, Reigosa MJ, Carballeira A (1991) Release of allelochemical agents from litter, throughfall, and topsoil in plantations of Eucalyptus globulus Labill in Spain. J Chem Ecol 17(1): $147-160$

Muller CH (1969) Allelopathy as a factor in ecological process Vegetatio 18: 48-357

Nilsson MC (1994) Separation of allelopathy and resource competition by the boreal dwarf shrub Empetrum hermaphroditum Oecologia 98: 1-7

Noble IR (1989) Attributes of invaders and the invading process: terrestrial and vascular plants. Pp 301-313 in Drake JA, Mooney HA, Di Castri F, Groves RH, Kruger FJ, Rejmanek M, Williamson M (eds). Scope 37: Biological Invasions: A Global Perspective. USA- New York: John Wiley and Sons

Oleszek WA, Hoagland RE, Zablotowicz RM (1999) Ecological significance of plant saponins Principles and Practices in Plant Ecology: 451-465

Orions GH (1986) Site characteristics favoring invasions. Pp 133-148 in: Drake JA, Mooney HA, Di Castri F, Groves RH, Kruger FJ, Rejmanek M, Williamson M (eds). Scope 37: Biological Invasions: A Global Perspective. USA-New York: John Wiley and Sons

Quayyum HA, Mallik AU, Orr DE, Lee PF (1999) Allelopathic potential of aquatic plants associated with wild rice: II. Isolation and identification of allelochemicals. J Chem Ecol 25(1): 221-228

Reichard SH (1997) Predicting invasions of woody plants introduced into North America. Conserv Biol 11: 193-202

Reigosa MJ, Gonzalez L, Souto XC, Pastoriza JE, (2000) Allelopathy in forest ecosystems. Pp 183-193 in Tauro P (eds) Allelopathy in Ecological Agriculture and Forestry. Netherlands: Kluwer Academic Publishers

Rejmanek M (1996) A theory of seed plant invasiveness: the first sketch. Biol Conserv 78: 171-181

Rice EL (1984) Allelopathy. $2^{\text {nd }}$ Ed GB-London: Academic press
Ridenour W, Callaway RM (2001) The relative importance of allelopathy in interference: the effects of an invasive weed on a native bunchgrass Oecologia 126(3): 444-450

Rutherford MC, Powrie LW (1993) Allelochemic control of biomass allocation in interacting shrub species. Journal of Chemical Ecology 19(5): 893-906

Scherrer B (1984) Biostatistique. Chicoutimi: Gaëtan Morin publ

Torck M, Pinkas M (1980) Sur quelques polyphénols de Medicago arborea L. (Légumineuses). Plantes Médicinales et Phytothérapie 1(1): 20-25

Vaughn SF, Berhow MA (1999) Allelochemicals isolated from tissues of the invasive weed garlic mustard (Alliaria petiolata). J Chem Ecol 25: 2495-2504

Vila M, D'Antonio CM (1998). Fruit choice and seed dispersal of invasive vs. non-invasive Carpobrotus (Aizoaceae) in coastal California. Ecology 79: 1053-1060

Vivanco J, Bias H, Stermitz F, Thelen G, Callaway R (2004) Biogeographical variation in community response to root allelochemistry: novel weapons and exotic invasion. Ecology Letters 7: 285-292

Vivrette NJ, Muller CH (1977) Mechanism of invasion and dominance of coastalgrassland by Mesembyranthemum crystallinum. Ecol Monogr 47: 301-318

Vyvyan JR (2002) Allelochemicals as leads for new herbicides and agrochemicals. Tetrahedron 58: 1631-1649

Williamson GB (1990) Allelopathy, Koch's postulates, and the neck riddle. $\mathrm{Pp}$ 143-162 in Grace JB, Tilman T (eds). Perspective on Plant Competition. USA-San Diego, CA Academic Press, Inc

Williamson M (1996) Biological Invasions. GB-London: Chapman and Hall

Williamson M (1999) Invasions. Ecography 22: 5-12

Wiser SK, Allen RB, Clinton PW, Platt KH (1998) Community structure and forest invasion by an exotic herb over 23 years. Ecology 79: 2071-2081

Xuan TD, Shinkichi T, Khanh TD, Min CI (2005) Biological control of weeds and plant pathogens in paddy rice by exploiting plant allelopathy: an overview Crop Protection 24: 197-206

Zedler PH, Scheid GA (1988) Invasion of Carpobrotus edulis and Salix lasiolepis after fire in a coastal chaparral site in Santa Barbara County, California. Madrono 35: 196-201 